\title{
The effects of gelatin supplementation prior to cooling on ram semen quality and fertility
}

\author{
Anderson Marques Pinto Bandeira ${ }^{1}$, José Eduardo Matos ${ }^{1}$, Alexandre Nízio Maria ${ }^{2}$, \\ Paulo César Falanghe Carneiro ${ }^{2}$, Phillip H. Purdy ${ }^{3}$, Hymerson Costa Azevedo ${ }^{1,2,4}$ \\ ${ }^{1}$ Universidade Federal de Sergipe, São Cristóvão, Brazil. \\ ${ }^{2}$ Embrapa Tabuleiros Costeiros, Empresa Brasileira de Pesquisa Agropecuária (EMBRAPA), Aracaju, SE, Brazil. \\ ${ }^{3}$ Agricultural Research Service (ARS), United States Department of Agriculture (USDA), Fort Collins, United States of America.
}

\begin{abstract}
The physical and chemical characteristics of gelatin have been used to justify its inclusion in extenders to preserve the sperm quality and improve results of cervical artificial insemination with cooled semen. The objective of this study was to evaluate the effects of gelatin supplementation in cooling extender on the quality and fertility of ram semen stored at $5^{\circ} \mathrm{C}$. Semen samples $(n=24)$ of Santa Inês rams $(n=6)$ were diluted in Glycine-Yolk-Milk extender without (control) or with $1.5 \%$ of gelatin. The samples were loaded into $0.25 \mathrm{~mL}$ straws, cooled to $5^{\circ} \mathrm{C}$ and stored vertically for 48 and 72 hours. Sample quality was evaluated using straw homogeneity tests based on $\mathrm{pH}$, osmolality and the proportion of spermatozoa (PS) in both upper and lower segments of straws (US and LS), analyses of sperm motility, plasma and acrosomal membrane integrity, and by fertility after artificial insemination. Differences between the US and LS of straws were found for $\mathrm{pH}$ and PS (\%). They were significant only in the control group at both times: $\mathrm{pH}-5.96$ vs. 5.71 at $48 \mathrm{~h}$ and 6.13 vs. 5.89 at $72 \mathrm{~h}$; PS - 21.66 vs. 78.34 at $48 \mathrm{~h}$ and 20.87 vs. 79.13 at $72 \mathrm{~h}$. Storage in gelatin had very little, to no effect on the sperm kinetics or on the sperm membrane integrity evaluations. The addition of gelatin to the extender did not affect the pregnancy rate which ranged from 4.4 to $26.1 \%$. We conclude that gelatin is effective in maintaining the physical and chemical homogeneity of the semen samples. Further research is needed in order to optimize the use of gelatin supplementation and elucidate any potential benefits.
\end{abstract}

Keywords: gelatinization, homogeneity, sperm sedimentation.

\section{Introduction}

Cooled semen has been used for many years as an important tool for the conservation, dissemination and transport of genetic sheep genetics (Evans and Maxwell, 1990; Salamon and Maxwell, 2000). Recent research continues to use basic systems to cool semen to 4 to $15^{\circ} \mathrm{C}$, diluents composed of whole, skim or reconstituted milk, Egg Yolk, Tris, Tes, fructose, glucose, citric acid and bovine serum albumin, or by commercial media such as OVIXcell (IMV technologies, France) which results in the ability to hold semen for 0 to 168 hours (Allai et al., 2015; Quan et al., 2016; Benmoula et al., 2017; Hashem et al., 2017;
Gheller et al., 2018; Falchi et al., 2018).

Cooling semen to $5^{\circ} \mathrm{C}$ can reduce the sperm metabolic activity and motility which will enable it to be stored prior to artificial inseminations - AI (Evans and Maxwell, 1990). However, Nagy et al. (2002), Rahman (2011) and El-Speiy et al. (2014) observed with rabbits and Salvador et al. (2006) observed with goats that the cooling and storage of liquid semen can promote sedimentation of sperm and diluent components leading to $\mathrm{pH}$ fluctuations and concentration of the metabolites. Consequently, the sperm quality when stored in an extender may depend on its position in the tube or straw, particularly when the samples are held in a vertical position prior to cooling or freezing.

Although most manuscript do not specify how the samples are positioned during cooling and transportation, many of the procedures keep the semen in a vertical position in glass or plastic tubes or even in vials such as those cited by Sousa and Bicudo (2003) and Yániz et al. (2005). In addition, some automated semen refrigeration and freezing systems arrange the doses upright during processing (Maia et al., 2009; Sicherle et al. 2011). All of these procedures and systems can lead to sedimentation of the sperm during sample processing, storage and cryopreservation.

It was suggested that supplementing semen extender with gelatin may prevent the sedimentation of sperm (Nagy et al., 2002; Yániz et al., 2005) and preserve the homogeneity of the medium (Santos et al., 2015). In addition, it was suggested that gelatin may protect boar sperm from cold shock (Corcini et al., 2011), reduce the metabolic demand on ram sperm (Yániz et al., 2005), increase the viscosity of cooled ram semen in such a way that it becomes temporarily solidified (Yániz et al., 2005) which may then decrease the semen backflow from the cervix to the vagina during the AI (Paulenz et al., 2010; Corcini et al., 2011).

Many of these hypotheses are assumed to be true but have not been fully tested. With sheep the glycine-yolk-milk cooling extender has been tested and shown to be efficient in preserving ram semen (Gonzalez and Costa, 2012; Falleiros et al., 2013), but the addition of gelatin to this extender has never been tested. Often, supplementing extenders with components that were not part of the original recipe can result in interactions that may be deleterious. Consequently, the aim of the present study was evaluate the effect of gelatin supplementation in glycine-yolk- 
milk cooling extender on the quality and use of ram semen preserved at $5^{\circ} \mathrm{C}$.

\section{Materials and Methods}

All procedures have been carried out in accordance with the Conselho Nacional de Controle de Experimentação Animal (CONCEA), law 11794/2008 (CEUA - Embrapa Tabuleiros Costeiros - Protocol number: 18112015.0001) for use of experimental animals.

The experimental activities were conducted between May and November, in Sergipe State, Brazil, in tropical semi-arid region (Lat.10³6’09.4”South; Long.37³8’30.3’West).

\section{Semen collection and processing}

Four ejaculates were collected from each of six Santa Inês rams using an artificial vagina, split and then diluted with either the control or gelatin-treated extender. A modified glycine-yolk-milk-medium GYM (Gonzalez and Costa, 2012) was used as the control and the treatment samples were diluted with the control medium supplemented with $1.5 \%$ commercial type B powder gelatin (Yániz et al., 2005) produced from pre-treated bovine skin or ossein (Dr. Oetker ${ }^{\mathrm{TM}}$, Brazil).

The $\mathrm{pH}$ of the semen diluted with each extender was measured and the samples were then loaded into $0.25 \mathrm{ml}$ straws containing $100 \times 10^{6}$ spermatozoa. The straws were arranged in a vertical position and cooled from $32^{\circ} \mathrm{C}$ to $5^{\circ} \mathrm{C}$ at $0.22^{\circ} \mathrm{C} / \mathrm{min}$ in a refrigerator designed to minimize an abrupt decrease in temperature due to contact of the straws with other surfaces. The cooling rate was measured using a digital thermometer BK Precision 710 (B\&K Precision Corp., USA) connected to a temperature sensor (Type K thermocouple) inserted into a straw filled with extender lacking sperm to record the temperature every minute (Thermolink Software w/RS-232). The samples were maintained at $5^{\circ} \mathrm{C}$ for 48 and 72 hours and then assessed for in vitro and in vivo quality.

Only fresh semen samples with a minimum quality were used in this study: at least vigor score of $3.0(0-5)$ and $80 \%$ motile spermatozoa (0-100\%) both evaluated subjectively under optical microscopy (400X magnification) and, $80 \%$ normal spermatozoa, using the same technique used to evaluate the acrosome of sperm in the cooled semen. Some analyzes such as acrosome integrity and plasma membrane integrity were measured on fresh semen diluted with GYM in order to establish a baseline for these characteristics.

\section{Evaluation of semen homogeneity}

Straws from both experimental groups were cut after cooling in order to divide their contents in upper (US) and lower (LS) segments. Contents of each segment were pooled by ram and transferred to microtubes for evaluation of $\mathrm{pH}$ ( $\mathrm{pH}$ meter), osmolality (vapor pressure osmometer) and to determine the proportion of spermatozoa (PS) in each segment. Aliquots, $10 \mu \mathrm{l}$, of the samples were diluted in $3.990 \mu \mathrm{l}$ of distilled water and the proportion of sperm in each segment was determined using a Neubauer chamber and a phase contrast microscope at $400 \mathrm{X}$ magnification. The semen homogeneity was determined by computing the differences between the US and LS for each treatment.

\section{Computerized assessment of sperm kinetics}

The Sperm Class Analyzer (SCA ${ }^{\mathrm{TM}}$, Microptc, Barcelona, Spain) was used to evaluate the motility characteristics of the samples with the following system setup: temperature $=37^{\circ} \mathrm{C}$; particle area between 30 to $70 \mathrm{~mm}^{2} ; \mathrm{VCL}=20<$ slow $<100<$ medium $<200<$ rapid; progressivity $>80 \%$ of STR; circular $<50 \%$ LIN; VAP points $=5$; connectivity $=12$. Aliquots of cooled semen from the entire straw were diluted in evaluation solution (X-Cell ${ }^{\mathrm{TM}}$, IMV Technologies, France), to $16 \times 10^{6}$ spermatozoa/ml. Aliquots $(3 \mu \mathrm{l})$ of this solution were placed in a Makler chamber (SefiMedical Instruments, Haifa, Israel) and placed on the stage of a Nikon 50i microscope for image capture that included 500 to 600 cells/analysis (3 to 4 fields with 150 to 200 cells/field). The analyzed parameters were total motility (TM), progressive motility (PM), curvilinear velocity (VCL), straight-line velocity (VSL), average path velocity (VAP), linearity (LIN), straightness (STR), amplitude of lateral head displacement (ALH), and flagellar beat-cross frequency (BCF).

\section{Acrosome integrity}

The percentage of spermatozoa with morphologically intact acrosomes (ACI) was determined following fixation of cells with $0.2 \%$ glutaraldehyde (Blom, 1973). Samples (100 sperm/sample) were evaluated using phase contrast microscopy (Nikon 50i; $1000 \mathrm{X}$ magnification) to determine the percentage of spermatozoa without acrosomal wrinkling.

\section{Plasma membrane integrity}

The technique described by Harrison and Vickers (1990) was used to evaluate the sperm plasma membrane integrity (PMI) using the combination of carboxyfluorescein diacetate (CFDA) and propidium iodide (PI). Aliquots of samples $(25 \mu \mathrm{l})$ were diluted in $250 \mu \mathrm{l}$ of evaluation solution $\left(\mathrm{X}-\mathrm{Ce}{ }^{\mathrm{TM}}\right.$, IMV Technologies, France), and $10 \mu \mathrm{l}$ of this mixture was transferred to a microtube containing staining solution (40 $\mu \mathrm{l})$ composed of sodium citrate (3\%), PI (7.3 $\mu \mathrm{M})$ and CFDA $(20.0 \mu \mathrm{M})$ in water. After incubation (10 min), 200 sperm per sample were counted under an epifluorescence microscope (Nikon Eclipse 50i; 1000X magnification; $505 \mathrm{~nm}$ emission filters). The spermatozoa were classified as intact plasma membrane - showing green fluorescent brightness (CFDA) over the head, including the acrosome area or with plasma membrane damaged - showing red fluorescent brightness (PI) on the head and /or the acrosome area. 


\section{Artificial insemination}

Santa Inês ewes $(n=182)$ were assigned to four experimental groups (45 or 46 ewes/group) based on their age and body condition score $(\geq 2.5$ using the range of scores from 0 to 5; Russel et al., 1969). The estrous cycle of the ewes was synchronized using sponges (medroxyprogesterone acetate - MAP, Progespon ${ }^{\mathrm{TM}}$, Schering-Plough, Cotia, São Paulo, Brazil), cloprostenol sodium (Prostaglandin F2 alpha - PGF2 $\alpha$, Sincrocio ${ }^{\mathrm{TM}}$, Ouro Fino, Cravinhos, São Paulo, Brazil), and 400 IU of equine chorionic gonadotropin (eCG, Novormon ${ }^{\mathrm{TM}}$, Schering-Plough, Cotia, São Paulo, Brazil) according to the protocol described by Antunes-Melo et al. (2015). The ewes were inseminated 50 hours after sponge removal and application of eCG, using a transcervical technique according to procedures described by Taqueda et al. (2011). The ewes were inseminated with either the control (GYM without gelatin) or treated semen (GYM $+1.5 \%$ gelatin) that had been cooled for either 48 or 72 hours. Semen from each ram was used to inseminate either 30 ewes per ram ( $n=4$ rams) or 31 ewes per ram ( $\mathrm{n}=2$ rams) for a total of 182 ewes.

The fertility was determined 39 to 48 days after the day of insemination using an ultrasound (Logic $\alpha 100$, General Electrics, Sao Paulo, Brazil) equipped with a $5 \mathrm{MHz}$ transrectal transducer and the pregnancy rate (number of ewes pregnant per number inseminated per treatment group) was determined.

\section{Experimental design and statistical analysis}

A randomized complete block design was used to analyze the in vitro data ( $\mathrm{n}=6$ blocks or rams), with four replications within the blocks $(n=4$ ejaculates/ram) totaling 24 replications. In the artificial insemination trial each experimental group had 45 or 46 replications represented by the number of ewes inseminated.

The statistical analyses were performed using the Shapiro-Wilk test to assess the normality of the distribution. Normal data ( $\mathrm{pH}$ and PS at $72 \mathrm{~h}$ and PM, VSL, LIN, STR at 48 and $72 \mathrm{~h}$ ) were analyzed using the analysis of variance General Linear Model (GLM), while the non-normal data (TM, VCL, VAP, ALH, BCF, ACI and PMI at 48 and $72 \mathrm{~h}, \mathrm{pH}$, Osmolality and SP at $48 \mathrm{~h}$ and Osmolality in $72 \mathrm{~h}$ ) were analyzed using the Wilcoxon non-parametric test. Pearson's Chi-Squared test was used to determine differences in pregnancy rates. A significance level of 0.05 was used and all analyses were performed using SPSS, version 15.0.

\section{Results}

The evaluation of the semen dose homogeneity ( $\mathrm{pH}$, osmolality and proportion of spermatozoa by US and LS), is presented in Table 1 . The $\mathrm{pH}$ levels of the control (6.47) and gelatin-treated samples (6.35) decreased after being maintained at $5^{\circ} \mathrm{C}$ for 48 and $72 \mathrm{~h}$ in both segments of the semen straws. At both evaluation times differences $(\mathrm{P}<0.05)$ between US and LS $\mathrm{pH}$ were observed in the control samples but not $(\mathrm{P}>0.05)$ in the samples diluted in extender containing gelatin. The $\mathrm{pH}$ was lower $(\mathrm{P}<0.05)$ in the LS than in the US in the control group. There were no differences $(\mathrm{P}>0.05)$ between the segments for osmolality for both control and gelatin group at 48 or $72 \mathrm{~h}$. The proportion of spermatozoa in the US and LS differed $(\mathrm{P}<0.05)$ in the control but not $(\mathrm{P}>0.05)$ in gelatin group regardless of the cooling time. There were higher $(\mathrm{P}<0.05)$ sperm proportions in the lower segments in control group at 48 and $72 \mathrm{~h}$.

Table 1. Semen dose homogeneity based on differences between upper (US) and lower (LS) segments of straws (mean \pm standard deviation) with ram semen diluted in medium with $1.5 \%$ gelatin and cooled at $5^{\circ} \mathrm{C}$ for 48 and 72 hours.

\begin{tabular}{lccccc}
\hline \multirow{2}{*}{ Parameter } & \multirow{2}{*}{ Segment } & \multicolumn{4}{c}{ Cooling Time (hours) } \\
\cline { 3 - 6 } & & Control & Gelatin & Control & Gelatin \\
\cline { 3 - 6 } & US & $5.96 \pm 0.33^{\mathrm{a}}$ & $5.86 \pm 0.28^{\mathrm{a}}$ & $6.13 \pm 0.20^{\mathrm{a}}$ & $5.89 \pm 0.21^{\mathrm{a}}$ \\
\cline { 3 - 6 } $\mathrm{pH}$ & LS & $5.71 \pm 0.31^{\mathrm{b}}$ & $5.84 \pm 0.32^{\mathrm{a}}$ & $5.89 \pm 0.25^{\mathrm{b}}$ & $5.87 \pm 0.21^{\mathrm{a}}$ \\
\hline Osmolality & US & $358.67 \pm 10.13$ & $367.25 \pm 13.96$ & $397.50 \pm 47.29$ & $435.13 \pm 82.40$ \\
(mOsm) & LS & $355.50 \pm 8.97$ & $371.92 \pm 11.43$ & $404.97 \pm 31.41$ & $410.63 \pm 40.87$ \\
\hline \multirow{2}{*}{ Sperm } & US & $21.66 \pm 16.18^{\mathrm{b}}$ & $50.56 \pm 4.79^{\mathrm{a}}$ & $20.87 \pm 18.92^{\mathrm{b}}$ & $51.88 \pm 8.76^{\mathrm{a}}$ \\
Proportion (\%) & LS & $78.34 \pm 16.18^{\mathrm{a}}$ & $49.44 \pm 4.79^{\mathrm{a}}$ & $79.13 \pm 18.92^{\mathrm{a}}$ & $48.12 \pm 8.76^{\mathrm{a}}$ \\
\hline
\end{tabular}

${ }^{a, b}$ Different letter indicates statistical difference $(\mathrm{P}<0.05)$ between segments of the same experimental group and parameter.

Storage in gelatin had very little or no effect on the sperm kinetic analysis (Tab. 2) as well as on the sperm membrane integrity evaluations (Tab. 3). While some statistical differences were observed, the meaning had no apparent biological significance.

After 48 hours, the gelatin-treated group exhibited lower values $(\mathrm{P}<0.05)$ for PM, VCL, VSL, VAP, STR and BCF, and similar values $(\mathrm{P}>0.05)$ for
TM, LIN and ALH when compared to the control. After 72 hours, the gelatin-treated group had lower values $(\mathrm{P}<0.05)$ of TM, PM and BCF, however, other parameters showed no differences $(\mathrm{P}>0.05)$ between the groups at this cooling time: VCL, VAP, LIN, STR and ALH.

The fresh semen diluted with GYM presented PMI $87.43 \pm 7.28 \%$ and ACI $99.35 \pm 0.88 \%$ (mean and standard deviation). Gelatin did not affect $(\mathrm{P}>0.05)$ the 
ACI of semen samples refrigerated for 48 hours but, compared to the control, the gelatin-treated group had higher $(\mathrm{P}<0.05) \mathrm{PMI}$ at this cooling time. No differences $(\mathrm{P}>0.05)$ in acrosomal or plasma membrane integrity were observed in the semen cooled for 72 hours. Furthermore, pregnancy rates for semen cooled either with or without gelatin were similar $(\mathrm{P}>0.05)$ at both times (Tab. 3).

Table 2. Sperm kinetics analysis (mean \pm standard deviation) of ram semen diluted in medium with $1.5 \%$ gelatin and cooled at $5^{\circ} \mathrm{C}$ for 48 and 72 hours.

\begin{tabular}{lccc}
\hline \multirow{2}{*}{ Kinetic Parameter } & Group & \multicolumn{2}{c}{ Cooling Time (hours) } \\
\cline { 3 - 4 } & & 98 & 92 \\
\hline Total motility TM (TM, \%) & Control & $98.2 \pm 2.7$ & $96.6 \pm 4.5^{\mathrm{a}}$ \\
\hline Progressive motility (PM, \%) & Gelatin & $97.2 \pm 3.0$ & $92.9 \pm 9.8^{\mathrm{b}}$ \\
\hline Curvilinear velocity (VCL, $\mu \mathrm{m} / \mathrm{s})$ & Control & $58.0 \pm 6.1^{\mathrm{a}}$ & $49.6 \pm 8.8^{\mathrm{a}}$ \\
& Gelatin & $46.2 \pm 4.0^{\mathrm{b}}$ & $41.9 \pm 8.7^{\mathrm{b}}$ \\
\hline Straight-line velocity (VSL, $\mu \mathrm{m} / \mathrm{s})$ & Control & $357.0 \pm 30.7^{\mathrm{a}}$ & $325.3 \pm 42.7$ \\
& Gelatin & $336.4 \pm 52.9^{\mathrm{b}}$ & $321.1 \pm 62.7$ \\
\hline Average path velocity (VAP, $\mu \mathrm{m} / \mathrm{s})$ & Control & $197.8 \pm 20.6^{\mathrm{a}}$ & $168.6 \pm 25.0$ \\
& Gelatin & $172.7 \pm 18.0^{\mathrm{b}}$ & $157.1 \pm 26.2$ \\
\hline Linearity (LIN, \%) & Control & $249.5 \pm 23.4^{\mathrm{a}}$ & $221.6 \pm 29.3$ \\
& Gelatin & $229.3 \pm 25.0^{\mathrm{b}}$ & $214.0 \pm 33.8$ \\
\hline Straightness (STR, \%) & Control & $55.5 \pm 4.8$ & $51.8 \pm 3.6$ \\
& Gelatin & $52.1 \pm 6.4$ & $49.7 \pm 6.3$ \\
\hline Amp. of lateral head displ. (ALH, $\mu \mathrm{m})$ & Control & $79.3 \pm 3.5^{\mathrm{a}}$ & $76.0 \pm 4.1$ \\
\hline Flagellar beat-cross frequency $(\mathrm{BCF}, \mathrm{Hz})$ & Gelatin & $75.4 \pm 2.8^{\mathrm{b}}$ & $73.4 \pm 3.5$ \\
\hline
\end{tabular}

${ }^{\mathrm{a}, \mathrm{b}}$ Means followed by different superscript letters indicate differences $(\mathrm{P}<0.05)$ between groups within each cooling time.

Table 3. Sperm integrity evaluations (mean \pm standard deviation) and fertility (mean) of ram semen diluted in medium with $1.5 \%$ gelatin and cooled at $5^{\circ} \mathrm{C}$ for 48 and 72 hours.

\begin{tabular}{lccc}
\hline \multirow{2}{*}{ Parameter } & \multirow{2}{c}{ Group } & \multicolumn{2}{c}{ Cooling Time (hours) } \\
\cline { 3 - 4 } Acrosome integrity (ACI, \%) & & 48 & 72 \\
\hline \multirow{2}{*}{ Plasma membrane integrity (PMI, \%) } & Control & $96.7 \pm 2.9$ & $96.6 \pm 3.5$ \\
& Gelatin & $96.2 \pm 3.2$ & $95.9 \pm 3.4$ \\
\hline Fertility (\%) & Control & $72.4 \pm 13.9^{\mathrm{b}}$ & $69.9 \pm 15.0$ \\
& Gelatin & $77.3 \pm 13.4^{\mathrm{a}}$ & $69.5 \pm 16.4$ \\
\hline
\end{tabular}

${ }^{\mathrm{a}, \mathrm{b}}$ Means followed by different superscript letters indicate differences $(\mathrm{P}<0.05)$ between groups within each cooling time.

\section{Discussion}

There are few reports on the use of gelatin with ram semen but it seems that the composition of the diluents, the proportion of gelatin, holding temperature, time of storage and state of the sperm sample (liquid or solid) may be responsible for the different effects of gelatin on the cooled semen quality and fertilizing potential. In this research, the gelatin reduced the sperm sedimentation and maintained the $\mathrm{pH}$ homogeneity of the cooled semen for 48 and 72 hours. The higher homogeneity may result in a more favorable environment because the evenly distributed buffers and sperm could reduce the magnitude of the natural occurring pH shifts (Nagy et al., 2002; Salvador et al., 2006; Rahman, 2011; El-Speiy et al., 2014; Santos et al., 2015). Normally the semen $\mathrm{pH}$ level should be maintained between 6.0 and 6.5 to sustain the viability of ram sperm (Bartoov et al., 1980). However, the natural production of lactic acid during the dilution and cooling phases of semen (Dziekónska et al., 2009) reduce the levels of intra and extracellular $\mathrm{pH}$ (Gadea, 
2003; Yániz et al., 2011) which was also observed in this research. Furthermore, because of the greater homogeneity of the solution, the cryoprotectant systems may better protect the sperm against thermal shocks (Holt, 2000; Corcini et al., 2011).

While the addition of gelatin to the extender was beneficial for maintaining a homogeneous environment, the obvious benefits for motion characteristics, membrane integrity and fertility were not apparent.

The addition of gelatin altered some of the sperm kinetic parameters in comparison to the control Although the differences were significant, they do not seem to have much biological importance especially if we consider that sperm will be exposed to the uterine environment and may alter their movement. The sperm in the gelatinized media had more curvilinear or irregular movements, evidenced by lower values of VSL, VAP and STR after 48 hours of storage. These motility patterns were similar to rabbit sperm diluted with gelatinized extender and refrigerated for 0 to 96 hours (López-Gatius et al., 2005). These observations are also consistent with Mortimer (1997) who reported that, the higher the viscosity of diluent, the lower the flagellar movement amplitude. Hirai et al. (1997) also observed that the proportion of progressively motile bull sperm, and their velocity, was reduced in highly viscous media. Perhaps, if analyses of these characteristics were performed immediately after collection and dilution and after 24 hours of holding at $5^{\circ} \mathrm{C}$, then an apparent benefit may have been observed.

We speculate that the reported variation in quality and fertility following gelatin supplementation may be attributed to a modulation of sperm capacitation by gelatin. During capacitation, binder of sperm proteins (BSP) from the seminal plasma interact with plasma membrane proteins and induce or regulate the capacitation process (Arangasamy and Singh, 2007; Arangasamy, 2010; Plante et al., 2016). Furthermore, all known BSP proteins will interact with gelatin but this does not have an apparent biological significance (Plante et al., 2016). Consequently, if a semen sample is supplemented with gelatin then the addition of this protein may occupy the BSPs thus altering or inhibiting capacitation. Following the same line, the gelatin can hypothetically play an important influence on the BSPs roles in sperm motility and viability, in the formation of the oviductal sperm reservoir, in the regulation of cell volume and possibly in the interaction between sperm and oocytes (Plante et al., 2016).

Therefore, we conclude that gelatin is effective in maintaining the physical and chemical homogeneity of a semen sample when held for prolonged periods of time at $5^{\circ} \mathrm{C}$ but the effects of gelatin supplementation on cooled ram sperm used for artificial insemination are still to be determined, especially considering that a small sample size of ewes were utilized in this study. Optimization of this treatment and further studies to confirm our results with higher number of samples are obviously needed to elucidate the gelatin effects on sperm physiology and fertility.

\section{Conflict of Interest}

None of the authors have any conflict of interest to declare.

\section{References}

Allai L, Druart X, Contell J, Louanjli N, Moulaa AB, Badi A, Essamadi A, Nasser B, El Amiri B. 2015. Effect of argan oil on liquid storage of ram semen in Tris or skim milk based extenders. Anim Reprod Sci, 160: 57-67.

Antunes-Melo KD, Oliveira VS, Santos ADF, Oliveira CA, Mendonça LM, Goveia JSS, Almeida TS. 2015. Use of reduced doses of eCG applied by different routes in the TAI program in Santa Ines sheep. Semin Ciências Agrárias, 36(3):1347-1354.

Arangasamy A, Singh LP. 2007. In-vitro capacitation of epididymal spermatozoa with heparin and gelatin binding buffalo seminal plasma proteins. Indian J Anim Sci, 77:549-552.

Arangasamy A. 2010. Effect of stallion seminal plasma proteins on in-vitro capacitation of equine spermatozoa. Indian J Anim Sci, 80:107-109.

Bartoov B, Bar-Sagie D, Mayevsky A. 1980. The effect of $\mathrm{pH}$ on ram sperm collective motility driven by mitochondrial respiration. Int J Androl, 3:602-612.

Benmoula A, Badi A, El Fadili M, El Khalil K, Allai L, El Hilali A, El Amiri B. 2017. Effect of season on scrotal circumference, semen characteristics, seminal plasma composition and spermatozoa motility during liquid storage in INRA180 rams. Anim Reprod Sci, 180:17-22.

Blom E. 1973. The ultrastructure of some characteristic sperm defects and a proposal for a new classification of the bull spermiogram. Nord Vet Med, 25:383-391.

Corcini CD, Moreira F, Pigozzo R, Varela Jr AS, Torres NU, Lucia Jr T. 2011. Semen quality and reproductive performance after artificial insemination with boar sperm stored in a gelatin-supplemented extender. Livest Sci, 138:289-292.

Dziekońska A, Fraser L, Strzeżek J. 2009. Effect of different storage temperatures on the metabolic activity of spermatozoa following liquid storage of boar semen. J Anim Feed Sci, 18:638-649.

El-Speiy ME, Elkomy AE, Kamel KI. 2014. Effect of adding protein high viscosity (gelatin) in Tris extender on semen conservation status, fertility rates, antioxidant status and sex ratio of rabbits. Glob Vet, 12:840-849.

Evans G, Maxwell WMC. 1990. Inseminación artificial de ovejas y cabras (Ed.). Zaragoza, España: Acribia, S.A.

Falchi L, Galleri G, Zedda MT, Paua S, Boglioloa L, Ariua F, Ledda S. 2018. Liquid storage of ram semen for $96 \mathrm{~h}$ : effects on kinematic parameters, membranes and DNA integrity, and ROS production. Livestock Science, 207:1-6.

Falleiros MB, Bicudo SD, Rodello L, Monteiro CD, Sakashita SM, Weiss RR. 2013. Implicações do uso do extrato de LBD (lipoproteínas de baixa densidade) ou da gema de ovo "purificada", sobre a motilidade e morfologia espermáticas no sêmen ovino refrigerado 
por 24 ou 48 horas. Vet Zootec, 20:307-317.

Gadea J. 2003. Review: Semen extenders used in the artificial insemination of swine. Span J Agric Res, 1:1727.

Gheller SMM, Corcini CD, Jorgea P, Guilherme R, Thomaz LJ, Fabiana M, Varela Junior AS. 2018. Gelatin protects ram semen stored for $72 \mathrm{~h}$ at $5^{\circ} \mathrm{C}$. Small Rumin Res, 158:54-56.

Gonzalez CIM, Costa JAA. 2012. Reprodução assistida e manejo de ovinos de corte (Ed). Brasília, Brazil: Embrapa. v. 1000. 176p.

Harrison RAP, Vickers SE. 1990. Use of fluorescent probes to assess membrane integrity in mammalian spermatozoa. J Reprod Fertil, 88:343-352.

Hashem EZ, Haddad R, Eslami M. 2017. Evaluation of ram semen enrichment with oleic acid on different spermatozoa parameters during low temperature liquid storage. Small Rumin Res, 150:30-39.

Hirai M, Cerbito WA, Wijayagunawardane MPB, Braun J, Leidl W, Ohosaki $K$, Matsuzawa $T$, Miyazawa K, Sato K. 1997. The effect of viscosity of semen diluents on motility of bull spermatozoa. Theriogenology, 47:1463-1478.

Holt WV. 2000. Basic aspects of frozen storage of semen. Anim Reprod Sci, 62:3-22.

López-Gatius F, Sances G, Sancho M, Yániz J, Santolaria P, Gutiérrez R, Núñez M, Núñez J, Soler C. 2005. Effect of solid storage at $15^{\circ} \mathrm{C}$ on subsequent motility and fertility of rabbit semen. Theriogenology, 64:252-260.

Maia MS, Bicudo SD, Azevedo HC, Sicherle CC, Sousa DB, Rodello L. 2009. Motility and viability of ram sperm cryopreserved in a Tris-egg yolk extender supplemented with anti-oxidants. Small Rumin Res, 85:85-90.

Mortimer ST. 1997. A critical review of the physiological importance and analysis of sperm movement in mammals. Hum Reprod Update, 3:403-439.

Nagy S, Sinkovics G, Kovács A. 2002. Viability and acrosome integrity of rabbit spermatozoa processed in a gelatin-supplemented extender. Anim Reprod Sci, 70:283-286

Paulenz H, Ádnøy T, Fossen OH, Söderquist L. 2010. Effect on field fertility of addition of gelatine, different dilution rates and storage times of cooled ram semen after vaginal insemination. Reprod Dom Anim, 45:706710.
Plante G, Prud'homme B, Fan J, Lafleur M, Manjunath P. 2016. Evolution and function of mammalian binder of sperm proteins. Cell Tissue Res, 363:105-127.

Quan GB, Wu GQ, Wang YJ, Li DJ, Ma Y, Hong QH. 2016. Effects of the Tris, Tes, or skim milk based extender on in vitro parameters of ram spermatozoa during liquid storage. Small Rumin Res, 134:14-21.

Rahman SAHA. 2011. Effect of gelatin addition to extender on semen quality of rabbit. Al- Mustansiriya $J$ Sci, 22:7-12.

Russel AJF, Doney JM, Gunn RG. 1969. Subjective assessment of body fat in sheep. J Agric Sci, 72 (3):451454.

Salamon S, Maxwell WMC. 2000. Storage of ram semen. Anim Reprod Sci, 62:77-111.

Salvador I, Yániz J, Viudes de Castro MP, Gómez EA, Silvestre MA. 2006. Effect of solid storage on caprine semen conservation at $5^{\circ} \mathrm{C}$. Theriogenology, 66:974-981.

Santos FCC, Corcini CD, Costa VGG, Gheller SMM, Nogueira CEW, da Rosa Curcio B, Varela Jr. AS. 2015. Effect of solid medium during cooled storage on stallion sperm parameters. Cryo Letters, 36:313-317. Sicherle CC, Maia MS, Bicudo SD, Rodello L, Azevedo HC. 2011. Lipid peroxidation and generation of hydrogen peroxide in frozen-thawed ram semen supplemented with catalase or Trolox. Small Rumin Res, 95:144-149.

Sousa DB, Bicudo SD. 2003. Inseminação artificial com sêmen ovino refrigerado por 24 horas e transportado no sistema Equitainer [in portuguese]. Rev Bras Reprod Anim, 27(3):330-332.

Taqueda GS, Azevedo HC, Santos EM, Matos JE, Bittencourt RF, Bicudo SD. 2011. Influence of anatomical and technical aspects on fertility rate based on sheep transcervical artificial insemination performance. Ars Vet, 27:127-133.

Yániz J, Martí JI, Silvestre MA, Folch J, Santolaria P, Alabart JL, López-Gatius F. 2005. Effects of solid storage of sheep spermatozoa at $15^{\circ} \mathrm{C}$ on their survival and penetrating capacity. Theriogenology, 64:18441851.

Yániz JL, Mateos JA, Santolaria P. 2011. Zwitterionic buffers preserve ram semen quality more efficiently than TRIS during storage at $15^{\circ} \mathrm{C}$. Small Rumin Res, 95:54-60. 